Original Article

\title{
First case of canine visceral leishmaniasis in the midwestern of Santa Catarina State, Brazil
}

\author{
Primeiros casos de leishmaniose visceral canina no Meio-oeste do Estado de Santa \\ Catarina, Brasil
}

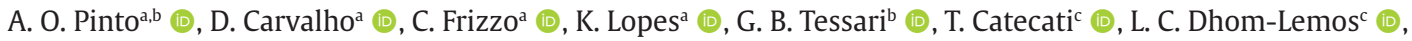 \\ A. K. S. Pasqualib (D, P. F. Quaresmac (D), P. H. Stococ (D), E. C. Grisardc (D), M. Steindel (D) and G. Wagner ${ }^{\mathrm{a}, \mathrm{c}^{*}}$ (D) \\ a Programa de Mestrado em Biociências e Saúde, Universidade do Oeste de Santa Catarina - UNOESC, Joaçaba, SC, Brasil \\ ${ }^{\mathrm{b} C}$ Curso de Graduação em Medicina Veterinária, Universidade do Oeste de Santa Catarina - UNOESC, Campos Novos, SC, Brasil \\ ${ }^{\mathrm{c}}$ Laboratório de Protozoologia, Universidade do Federal de Santa Catarina - UFSC, Florianópolis, SC, Brasil
}

\begin{abstract}
Canine visceral leishmaniasis (CVL) caused by Leishmania (Leishmania) infantum is transmitted by phlebotomine sandflies and a major zoonotic disease in Brazil. Due to the southward expansion of the disease within the country and the central role of dogs as urban reservoirs of the parasite, we have investigated the occurrence of CVL in two municipalities Erval Velho and Herval d'Oeste in the Midwest region of Santa Catarina state. Peripheral blood samples from 126 dogs were collected in both cities and tested for anti-L. infantum antibodies by indirect enzymelinked immunosorbent assay (ELISA) and indirect immunofluorescence reaction (IIF) and for the presence of parasite DNA by polymerase chain reaction (PCR) in peripheral blood. From examined dogs, 35.71\% (45/126) were positive for at least one of the three tests and two (1.6\%) were positive in all performed tests. Twelve dogs (9.5\%) were positive for both ELISA and IIF, while 21 dogs were exclusively positive for ELISA (16.7\%), and 15 (11.9\%) for IIF. L. infantum k-DNA was detected by PCR in 9 out of 126 dogs (7.1\%) and clinical symptoms compatible with CVL were observed for 6 dogs. Taken together, these results indicate the transmission of CVL in this region, highlighting the needs for epidemiological surveillance and implementation of control measures for CVL transmission in this region.
\end{abstract}

Keywords: visceral leishmaniasis, public health, dog, zoonosis.

\section{Resumo}

A Leishmaniose Visceral Canina (LVC) causada pela Leishmania (Leishmania) infantum e transmitida por flebotomíneos e é uma das principais zoonoses do Brasil que se encontra em expansão em estados da região sul do país, sendo os cães o principal reservatório urbano do parasito. O presente estudo investigou a ocorrência de LVC em dois municípios, Erval Velho e Herval d'Oeste localizados no meio-oeste de Santa Catarina. Para tanto, amostras de sangue periférico de 126 cães foram coletadas em ambas as cidades e submetidas à detecção de anticorpos anti-L. infantum por meio de testes de ELISA e imunofluorescência indireta (IFI), bem com a detecção de k-DNA pela reação em cadeia de polimerase (PCR). Além disso, também foram observados os sintomas clínicos e as condições ambientais associadas a esses animais. Dos cães examinados, 35,7\% (45/126) foram positivos para pelo menos um dos três testes, dois cães (1,6\%) foram positivos em todos os três testes, 12 cães (9,5\%) foram positivos tanto no ELISA quanto na IFI, enquanto 21 cães (16,7\%) foram positivos para ELISA e 15 (11,9\%) para o IFI. A amplificação do k-DNA de L. infantum foi positiva em 9 dos 126 cães (7,1\%). Entre os cães positivos seis apresentaram um ou mais sintomas clínicos correlacionados com a LVC. Esses resultados confirmaram a ocorrência de LVC na região e destacaram a importância do monitoramento e implementação de medidas de controle para a LVC nessa região

Palavras-chave: leishmaniose visceral, saúde pública, cães, zoonose.

\section{Introduction}

Visceral leishmaniasis (VL) also known as 'kalaazar' is a life-threatening parasitic disease caused by parasites belonging to the Leishmania donovani complex (Akhoundi et al., 2016). Leading to high lethality rates when untreated, VL has the third-largest mortality rate among parasitic diseases after malaria and schistosomiasis,

being responsible for around 50,000 deaths annually (Marzochi et al., 2014; WHO, 2017). As reviewed by TorresGuerrero et al. (2017), around 90\% of all VL cases occur in India, Bangladesh, Nepal, Brazil, and Sudan.

The protozoan parasite Leishmania (Leishmania) infantum Nicolle, 1908, the etiologic agent of American visceral

*e-mail: glauber.wagner@ufsc.br

Received: July 20, 2020 - Accepted: November 28, 2020 
leishmaniasis (AVL) is transmitted among its mammalian hosts through the bite of female sandflies, notably, Lutzomyia longipalpis Lutz \& Neiva, 1912 (Dvorak et al., 2018). In Brazil, the urbanization of VL has been associated with a variety of anthropic actions such as environmental changes and population migration, that leads to displacement or introduction of sylvatic reservoirs and infected dogs to areas with no previous transmission, and to adaptation of Lutzomyia longipalpis to the peridomiciliary environment (Maia-Elkhoury et al., 2008; Rocha et al., 2018). From the 59,129 VL cases reported between 1980 and 2005 in Brazil, the majority occurred in the Northeastern region of the country (82.5\%), however, revealing a gradual spreading pattern to other regions. Visceral leishmaniasis is highly prevalent in dogs found in both rural and urban areas of several Latin American countries, where canine infection usually precedes outbreaks of human visceral leishmaniasis (Coura-Vital et al., 2011; Cunha et al., 2012).

So far, autochthonous canine visceral leishmaniasis $(\mathrm{CVL})$ transmission was reported in the southern Brazilian states of Rio Grande do Sul, Santa Catarina, and Paraná (Deboni et al., 2011; Steindel et al., 2013; Maziero et al., 2014; Pasquali et al., 2019; Dias et al., 2020). In Santa Catarina state, CVL was originally reported in the eastern coastal city of Florianopolis in 2010 and, according to the local Center for Zoonotic Diseases Control (CCZ), since then a total of $481 \mathrm{CVL}$ cases were confirmed among 14,190 dogs tested (Florianópolis, 2020). In the western region of the State, where it shares borders with Argentina, an infection rate of $16.2 \%$ was detected in 252 dogs by serological and PCR tests in the municipalities of São Miguel do Oeste and Descanso (Maziero et al., 2014). Following the reports of CVL occurrence, the first cases of human visceral leishmaniasis (HVL) in southern Brazil were reported in São Borja municipality at the Rio Grande do Sul State in 2009 (Deboni et al., 2011), in Foz do Iguaçu municipality at Paraná State in 2016 (Pina-Trench et al., 2016), and in Florianópolis city, Santa Catarina State, in 2017 (Brasil, 2020).

Considering the polar reports of CVL in the eastern and western extremes of the Santa Catarina State, in the present study we investigated the occurrence of CVL in two municipalities (Herval D'Oeste and Erval Velho), located in the midwest region of Santa Catarina State.

\section{Materials and Methods}

\subsection{Sample collection}

The study was approved by the Committee on Ethics in Animal Use (CEUA) of the Universidade do Oeste de Santa Catarina - UNOESC (Protocol: 007/2015). Blood samples $(5 \mathrm{~mL})$ were collected by venipuncture using dry and EDTA-containing tubes for serological and PCR analysis, respectively, from 126 dogs from two neighboring municipalities, Herval d'Oeste (87 samples) and Erval Velho (39 samples). Buffy coats were isolated using Histopaque ${ }^{\circledR}$ (Sigma) and were stored at $-20{ }^{\circ} \mathrm{C}$ along with the serum samples until use. Each dog was clinically evaluated by a veterinarian for CVL signs and symptoms and a structured questionnaire was applied to each dog owner to collect data (name, race, sex, age, origin, housing, stray or guarded maintenance) and environmental information associated with dog farming in the peridomicile and the proximity of wet forest areas (Mixed Ombrophilous Forest).

\subsection{Serological assays}

Serological analysis was performed using an in-house enzyme-linked immunosorbent assay (ELISA) and indirect immunofluorescence (IIF) test. Promastigotes of the reference $L$. infantum strain (MHOM/FR/71/LRM75) were cultured at $26{ }^{\circ} \mathrm{C}$ in Schneider's medium supplemented with $5 \%$ Fetal Bovine Serum (FBS) and 2\% of sterile human urine were collected at the exponential growth phase $\left(5 \times 10^{7} / \mathrm{mL}\right)$, washed three times in PBS $\mathrm{pH} 7.4$, resuspended in $2 \mathrm{~mL}$ of PBS containing a protease inhibitors cocktail and Merthiolate $1: 10,000$ and submitted to three sonication cycles at $40 \mathrm{~Hz} / 1 \mathrm{~min}$ at $4{ }^{\circ} \mathrm{C}$ and gently mixed at $4{ }^{\circ} \mathrm{C}$ overnight. After that, the lysate was centrifuged $5,000 \times g / 1 \mathrm{~h}$ at $4{ }^{\circ} \mathrm{C}$ and the supernatant was collected for protein quantification by the Bradford method. ELISA microtiter immunoassay 96-well plates MaxiSorp ${ }^{\mathrm{TM}}$ (Nunc, Roskilde, Denmark) were coated with L. infantum lysate ( $50 \mathrm{ng} /$ well; $100 \mu$ l total volume) in carbonate/bicarbonate buffer pH 9.5 for $12 \mathrm{~h}$ at $4{ }^{\circ} \mathrm{C}$. After coating, four washes were performed with $200 \mu$ l of washing buffer containing PBS pH 7.4 and $0.5 \%$ Tween 20, following incubation with a blocking buffer consisting of $5 \%(\mathrm{w} / \mathrm{v})$ non-fat milk for $1 \mathrm{~h}$ at room temperature (RT). The assay was performed using serum samples diluted 1:200 and secondary anti-Dog IgG HRP Conjugated (1:2,500), Immunology Consultants Laboratory, USA) as previously described (Castro et al., 2003). Based on the ROC curve obtained using positive and negative control serum samples, the cut-off value for positive samples was set as 0.22 .

IIF assays were performed as previously described (Moraes et al., 2008; Szargiki et al., 2009). Briefly, L. infantum promastigotes were harvested on the exponential growth phase in vitro, washed three times in $\mathrm{PBS}$ pH 7.4 containing $0.1 \%$ glucose, and fixed in paraformaldehyde $2 \%$ in PBS (v/v) for 2 hours at $4{ }^{\circ} \mathrm{C}$. Fixed parasites were then washed twice in PBS pH 7.4 and had their final concentration was adjusted to $1 \times 10^{6}$ parasites/ml in PBS supplemented with $1 \%$ bovine serum albumin (BSA). The cells were then distributed ( $5 \mu \mathrm{l} /$ well) in 12 well IIF slides, air-dried, and stored at $-20{ }^{\circ} \mathrm{C}$. Parasites were then incubated for $1 \mathrm{~h}$ with serial dilutions (1:40 to 1:320) of each serum sample. After washing twice with PBS pH 7.4 and drying at RT, parasites were then incubated for $1 \mathrm{~h}$ with a $1: 100$ dilution of a FITC- conjugated anti-dog IgG antibody (Immunology Consultants Laboratory, USA). Positive and negative serum controls were included in each slide.

\subsection{Molecular assays (PCR)}

Total DNA was extracted from buffy coats through the standard phenol/chloroform method (Sambrook and Russel, 2001). PCR detection of L. infantum targeted conserved kinetoplast DNA sequences as formerly described (Lachaud et al., 2002; Marcondes et al., 2009). The reaction was performed in a final volume of $10 \mu \mathrm{L}$ containing $5 \mu \mathrm{L}$ 
GoTaq $^{\circledR}$ Green Master Mix (Promega, USA), 0.16 pmol of each primer (RV1F 5'-CTT TTC TGG TCC CGC GGG TAG G-3' and RV2R 5'-CCA CCT GGC CTA TTT TAC ACC A-3'), and $1 \mu \mathrm{L}$ of template DNA from buffy coats. The PCR cycling conditions were as follows: initial denaturation at $95^{\circ} \mathrm{C}$ for $5 \mathrm{~min}$; followed by 35 cycles of denaturation $\left(95^{\circ} \mathrm{C}\right.$, $1 \mathrm{~min})$, annealing $\left(60^{\circ} \mathrm{C}, 30 \mathrm{~s}\right)$, and extension $\left(72^{\circ} \mathrm{C}, 30 \mathrm{~s}\right)$; and final extension $\left(72{ }^{\circ} \mathrm{C}, 5 \mathrm{~min}\right)$. Positive (DNA from L. infantum MHOM/FR/71/LRM75, Leishmania braziliensis MHOM/BR/75/M-2904, and L. amazonensis MHOM/BR/77/ LTB0016) and negative (no DNA added) were included in each reaction set. PCR products were then resolved in $1 \%$ agarose-TBE gels, stained with ethidium bromide, and digitally recorded.

\subsection{Statistical analysis}

Statistical significance was analyzed using the chi-square test or Fisher's exact test $(p<0.05)$. Odds ratio (OR), which indicated the measure of association, was also calculated at a $95 \%$ confidence interval $(\mathrm{CI})$.

\section{Results}

Considering the fundamental role of dogs in the Leishmania transmission cycle as reservoirs of L. infantum in both urban and periurban environments and considering the control measures for visceral leishmaniasis recommended by the Brazilian Health Ministry (BHM), the monitoring of parasite infection in these animals becomes crucial. The current diagnostic protocol of BHM recommends the use of two serological tests: an immunochromatographic test (TR DPP ${ }^{\circledR}$, Bio-Manguinhos, Brazil) for serological screening and a downstream ELISA assay as a confirmatory test for the DPP-positive animals. Due to the lack of quantitative results of the TR DPP ${ }^{\circledR}$ test, we opted to evaluate the seropositivity of dogs for CVL using ELISA and IIF tests. A summary of the results is presented in Table 1.

Among the 126 dogs evaluated, $16.7 \%$ were positive for ELISA and $11.9 \%$ for IIF. PCR revealed the amplification of the 145 bp-specific $L$. infantum k-DNA fragment in $7.1 \%$ of the samples. Fourteen dogs (11.1\%) tested positive for at least two tests, revealing concordance between ELISA and IIF for 12 (9.5\%) dogs and between serological and PCR for four $(3.17 \%$ ) dogs, and an overall infection rate of $35.41 \%$ (Table 1). Sera from these two animals were further tested by ELISA and IFF by an independent private laboratory in Brazil, which has confirmed to be positive for CVL.

Among the dogs tested positive for CVL in at least two methods ( $n=14$ ), $42.85 \%$ presented one or more clinical symptoms such as weight loss (14.3\%), generalized alopecia (42.9\%), ear and nose lesions (28 and 57\%, respectively), onychogryphosis, lymphadenopathy, and irregular fever $(7.1 \%)$. It is noteworthy to mention that a single asymptomatic dog from Herval d'Oeste revealed positive by both ELISA and PCR. Also, all dogs tested negative for all methods were asymptomatic.

All CVL-positive dogs had defined owners and lived closer $(<300 \mathrm{~m})$ to remnants of sub-tropical forested areas (Mixed Ombrophilous Forest), to which they have free access (rural free-ranging owned dogs) and $92.9 \%$ of CVL-positive dogs live closer to poultry and swine farms that are the most important rural activities in that region odds ratio $(p>0.05)$.

\section{Discussion}

Although no records of the presence of L. infantum in the Midwest region of Santa Catarina State have been demonstrated so far, recent studies have indicated the expansion of CVL for indene regions in this state (Maziero et al., 2014). In the present study, L. infantum was found in dogs from Erval Velho and Herval d'Oeste municipalities at Santa Catarina State using serological and molecular (PCR) methods. Maziero et al. (2014) showed that $16.2 \%$ of dogs from São Miguel do Oeste and Descanso municipalities located in the western region of the state revealed positive by ELISA and IIF tests. In Florianópolis, an endemic area since 2010, where $\mathrm{Lu}$. longipalpis was not found, the reported seroprevalence for L. infantum in dogs is 3.3\% according to the Zoonosis Control Center. In the neighboring states of Rio Grande do Sul and Paraná, were the canonical vector $\mathrm{Lu}$. longipalpis is present, CVL has been reported in 2008 and 2012, respectively. In the Rio Grande do Sul a survey in 34 municipalities showed a seroprevalence of $20.8 \%$ among 5,430 dogs evaluated (Deboni et al., 2011). In contrast, on the tri-border frontier (Brazil, Argentina, Paraguay) located in Foz do Iguaçu

Table 1. Distribution of the CVL cases detected in Erval Velho and Herval d'Oeste municipalities at the midwestern region of Santa Catarina State (Brazil), according to the diagnostic methods (ELISA, IIF or PCR).

\begin{tabular}{|c|c|c|c|c|c|c|}
\hline \multirow{3}{*}{ Method } & \multicolumn{4}{|c|}{ Municipalities } & \multirow{2}{*}{\multicolumn{2}{|c|}{ Total $(n=126)$}} \\
\hline & \multicolumn{2}{|c|}{ Erval Velho $(n=39)$} & \multicolumn{2}{|c|}{ Herval d'Oeste $(n=87)$} & & \\
\hline & $\operatorname{Pos}(\%)$ & $\operatorname{Neg}(\%)$ & $\operatorname{Pos}(\%)$ & $\operatorname{Neg}(\%)$ & $\operatorname{Pos}(\%)$ & $\operatorname{Neg}(\%)$ \\
\hline ELISA & $17(43.6)$ & $22(56.4)$ & $4(4.6)$ & $83(95.4)$ & $21(16.7)$ & $105(83.3)$ \\
\hline IIF & $14(35.9)$ & $25(64.1)$ & $1(1.2)$ & $86(98.9)$ & 15 (11.9) & $111(88.1)$ \\
\hline PCR & $3(7.7)$ & $36(92.3)$ & $6(6.9)$ & $81(93.1)$ & $9(7.1)$ & 117 (92.9) \\
\hline Two Methods & $13(33.3)$ & $26(66.7)$ & $1(1.1)$ & $86(98.9)$ & $14(11.1)$ & $112(88.9)$ \\
\hline
\end{tabular}

Pos = Positive; Neg = Negative. 
(Paraná state), 3.9\% of 681 dogs presented anti-Leishmania spp. antibodies (Dias et al., 2018).

Considering the PCR results, $7.1 \%$ of the dogs were positive for the presence of $L$. infantum in the peripheral blood, although detection of $L$. infantum by PCR from blood samples (buffy coat) is less sensitive for CVL diagnosis than sampling bone marrow or popliteal lymph nodes (Silveira et al., 2018; Marcelino et al., 2020). Studies carried out in the states of Minas Gerais and Mato Grosso do Sul using blood samples revealed $24.7 \%$ and $47.5 \%$ of positive PCR, respectively (Coura-Vital et al., 2011; Cunha et al., 2012). In the study of Maziero et al. (2014) carried out in the municipalities of Descanso and São Miguel do Oeste, at the west region of Santa Catarina, using blood samples, $21 \%$ of the 252 evaluated dogs showed PCR positivity.

The western region of Santa Catarina was once considered non-endemic for CVL and Lu. longipalpis was absent in this region (Orlandin et al., 2019). These authors have although confirmed the presence of Migonemyia migonei and Pintomyia fischeri in the region. Recently, $L$. infantum PCR positive infection was shown in P. fischeri in an endemic area of VL in São Paulo, Brazil (Galvis-Ovallos et al., 2021). Besides that, M. migonei was found naturally infected by L. infantum for the first time in a VL endemic area in Pernambuco, where Lu. longipalpis is absent (Carvalho et al., 2010), and also in Argentina (Moya et al., 2015), suggesting that other sandfly species may be involved in L. infantum transmission.

Maziero et al. (2014) reported for the first time the occurrence of CVL at the western border of Santa Catarina State (Brazil) with Argentina. Previously, Figueiredo et al. (2012) and Steindel et al. (2013) reported the first cases of CVL in Florianópolis, located on the eastern sea border of Santa Catarina State in 2010, showing that the possibly introduction of L. infantum in Florianópolis might have occurred via introduction from endemic Brazilian states or even from other endemic countries since Florianópolis is the Mercosul capital of tourism and one of the preferred holydays destinations in Brazil. On the other hand, the introduction of $L$. infantum in the western region might have occurred via dry borders with Argentina and Paraguay. The western region of Santa Catarina is the highest producer of swine and poultry in Brazil and the main grain transportation route between Rio Grande do Sul, Paraná and Mato Grosso states as well as neighboring countries from the Southern Cone of Latin America (Argentina, Uruguay, Chile and Paraguay). Thus the actual occurrence of L. infantum in western Santa Catarina could probability have been introduced via these commercial routes or human migration, since the CVL is present the province of Misiones in Argentina (Salomon et al., 2008) and the L. infantum is wider distributed from Rio Grande do Sul State and Paraguay to the southern cone of South America (Ferreira et al., 2012). However, recently Pasquali et al. (2019) hypothesize that the dispersion of L. infantum in the west region of Santa Catarina could be due to a new introduction, might event due from import from the old-world strains, which requires further investigation. Thus, origins and dispersion of L. infantum in the west of Santa Catarina State still remains to be addressed from the molecular point of view, but the lower prevalence of positive dogs in these two municipalities located on the midwestern part of the state may suggests a recent introduction of $L$. infantum in that region.

Compatible CVL symptoms were observed for $42.85 \%$ of the positive dogs, being in accordance to the observations by Maziero et al. (2014) were 39.6\% of the dogs presented CVL symptoms. In addition, all positive dogs live less than 300 meters away to wet vegetation (Mixed Ombrophilous Forest) and they have free access to the forest, which increased the chances of CVL infection, reinforcing the zoonotic potential of the disease. Another important observation was that $92.9 \%$ of the CVL-positive dogs live close to poultry breeding areas $(p>0.05)$ that are largely present on this region. Altogether, our results reinforce the spreading of canine visceral leishmaniasis and alert the local health authorities to the urgent need for epidemiological surveillance for human visceral leishmaniasis in that region.

\section{Conclusion}

Results of serological and PCR assays indicate the presence of canine visceral leishmaniasis in the two neighboring municipalities of Erval Velho and Herval d'Oeste in the Midwest region of Santa Catarina State (Brazil). Along with the reports of $L$. infantum infection in dogs in the western and eastern regions, this study reveals that autochthonous CVL occurs in this southern Brazilian state and further epidemiological assessment is necessary. Also, biological characterization of parasite isolates and continuous vector surveillance is thus necessary towards decision-making for appropriate actions for controlling this disease transmission among dogs, thereby avoiding the transmission of VL to humans.

\section{Acknowledgements}

We are thankful to all dog owners and the Nongovernmental organization "Voluntários Amigos dos Animais of Joaçaba and Herval d' Oeste" by their assistance on the collection samples and the permission to collect the samples. This work was supported by Unoesc (University of West Santa Catarina) (Grant: FAPE/2015), CAPES (Coordination for the Improvement of Higher Education Personnel), CNPq(National Council for Scientific and Technological Development) and UFSC (Federal University of Santa Catarina).

\section{References}

AKHOUNDI, M., KUHLS, K., CANNET, A., VOTÝPKA, J., MARTY, P., DELAUNAY, P. and SERENO, D., 2016. A historical overview of the classification, evolution, and dispersion of Leishmania parasites and sandflies. PLoS Neglected Tropical Diseases, vol. 10, no. 3, pp. e0004349. http://dx.doi.org/10.1371/journal. pntd.0004349. PMid:26937644.

BRASIL. Departamento de Informática do Sistema Único de Saúde - DATASUS, 2020 [viewed 30 June 2020]. Leishmaniose visceral: casos confirmados notificados no Sistema de Informação de Agravos de Notificação - Sinan Net [online]. Available from: http://tabnet. datasus.gov.br/cgi/tabcgi.exe?sinannet/leishvi/bases/leishvbrnet.def 
CARVALHO, M.R., VALENÇA, H.F., SILVA, F.J., PITA-PEREIRA, D., ARAÚJO PEREIRA, T., BRITTO, C., BRAZIL, R.P. and BRANDÃO FILHO, S.P., 2010. Natural Leishmania infantum infection in Migonemyia migonei (Franc, a, 1920) (Diptera:Psychodidae:Phlebotominae) the putative vector of visceral leishmaniasis in Pernambuco State, Brazil. Acta Tropica, vol. 116, no. 1, pp. 108-110. http:// dx.doi.org/10.1016/j.actatropica.2010.03.009. PMid:20457120.

CASTRO, E.A., THOMAZ-SOCCOL, V. and AUGUR, C., 2003. Standardization of ELISA (Enzyme linked immunosorbent Assay) and Indirect Fluorescent Antibody Test (IFAT) techniques for canine cutaneous Leishmaniasis. In: S. ROUSSOS, C.R. SOCCOL, A. PANDEY and C. AUGUR, eds. New horizons in biotechnology. Netherlands: Kluwer Academic Publishers. http://dx.doi. org/10.1007/978-94-017-0203-4_34.

COURA-VITAL, W., MARQUES, M.J., VELOSO, V.M., ROATT, B.M., AGUIAR-SOARES, R.D.O., REIS, L.E.S., BRAGA, S.L., MORAIS M.H.S., REIS, A.B. and CARNEIRO, M., 2011. Prevalence and factors associated with Leishmania infantum infection of dogs from an urban area of Brazil as identified by molecular methods. PLoS Neglected Tropical Diseases, vol. 5, no. 8, pp. e1291. http:// dx.doi.org/10.1371/journal.pntd.0001291. PMid:21858243.

CUNHA, R.C., ANDREOTTI, R., SILVA, E., PEREIRA, E., SATO, T. and THOMAZSOCCOL, V., 2012. Laboratory diagnosis and clinical signs of canine visceral leishmaniasis in dogs examined at the center for zoonosis control in Campo Grande - MS. Archives of Veterinary Science, vol. 17, no. 4, pp. 17-26. http://dx.doi.org/10.5380/avs.v17i4.24951.

DEBONI, S.C., BARBOSA, M. and RAMOS, R.R., 2011. Leishmaniose Visceral no Rio Grande do Sul. Boletim Epidemiológico, vol. 13, no. 1, pp. 1-3.

DIAS, R.C.F., PASQUALI, A.K.S., THOMAZ-SOCCOL, V., POZZOLO, E.M., CHIYO, L., ALBAN, S.M., FENDRICH, R.C., ALMEIDA, R.A.A., FERREIRA, F.P., CALDART, E.T., FREIRE, R.L., MITSUKA-BREGANÓ, R., BISETTO JÚNIOR, A. and NAVARRO, I.T., 2020. Autochthonous canine visceral leishmaniasis cases occur in Paraná state since 2012: isolation and identification of Leishmania infantum. Revista Brasileira de Parasitologia Veterinária, vol. 29, no. 1, pp. e009819. http://dx.doi.org/10.1590/s1984-29612019083. PMid:31691734.

DIAS, R.C.F., THOMAZ-SOCCOL, V., PASQUALI, A.K.S., ALBAN, S.M., FENDRICH, R.C., POZZOLO, E.M., CHIYO, L., BISETTO JÚNIOR, A., FERREIRA, F.P., DESTO, S.S., FREIRE, R.L., MITSUKA-BREGANÓ, R. and NAVARRO, I.T., 2018. Variables associated with the prevalence of anti-Leishmania spp. antibodies in dogs on the tri-border of Foz do Iguaçu, Paraná, Brazil. Revista Brasileira de Parasitologia Veterinária, vol. 27, no. 3, pp. 338-347. http:// dx.doi.org/10.1590/s1984-296120180055. PMid:30184001.

DVORAK, V., SHAW, J. and VOLF, P., 2018. Parasite biology: the vectors. In: F. BRUSCHI and L. GRADONI, eds. The leishmaniases: old neglected tropical diseases. Switzerland: Springer, pp. 31-77. http://dx.doi.org/10.1007/978-3-319-72386-0_3.

FERREIRA, G.E., SANTOS, B.N., DORVAL, M.E., RAMOS, T.P., PORROZZI, R., PEIXOTO, A.A. and CUPOLILLO, E., 2012. The genetic structure of Leishmania infantum populations in Brazil and its possible association with the transmission cycle of visceral leishmaniasis. PLoS One, vol. 7, no. 5, pp. e36242. http://dx.doi.org/10.1371/ journal.pone.0036242. PMid:22606248.

FIGUEIREDO, F.B., LIMA JÚNIOR, F.E.F., TOMIO,J.E., INDÁ, F.M.C., CORRÊA, G.L.B. and MADEIRA, M.F., 2012. Leishmaniose visceral canina: dois casos autóctones no município de Florianópolis, Estado de Santa Catarina. Acta Scientiae Veterinariae, vol. 40, no. 1, pp. 1026.

FLORIANÓPOLIS. Centro de Controle de Zoonoses - CCZ, 2020 [viewed 30 June 2020]. [online]. Florianópolis: Secretaria de Saúde do Município. Available from: http://www.pmf.sc.gov. br/entidades/saude/index.php?cms=centro+de+controle+de+ zoonoses +++ ccz\&menu=0
GALVIS-OVALLOS, F., UETA, A.E., MARQUES, G.O., SARMENTO, A.M.C., ARAUJO, G., SANDOVAL, C., TOMOKANE, T.Y., MATTA, V.L.R., LAURENTI, M.D. and GALATI, E.A.B., 2021. Detection of Pintomyia fischeri (Diptera: Psychodidae) with Leishmania infantum (Trypanosomatida: Trypanosomatidae) promastigotes in a focus of visceral leishmaniasis in Brazil. Journal of Medical Entomology, vol. 58, no. 2, pp. 830-836. http://dx.doi.org/10.1093/ jme/tjaa199. PMid:33047129.

LACHAUD, L., MARCHERGUI-HAMMAMI, S., CHABBERT, E., DEREURE, J., DEDET, J.P. and BASTIEN, P., 2002. Comparison of six PCR methods using peripheral blood for detection of canine visceral leishmaniasis. Journal of Clinical Microbiology, vol. 40, no. 1, pp. 210-215. http://dx.doi.org/10.1128/JCM.40.1.210-215.2002. PMid:11773118.

MAIA-ELKHOURY, A.N.S., ALVES, W.A., SOUSA-GOMES, M.L., SENA, J.M. and LUNA, E.A., 2008. Visceral leishmaniasis in Brazil: trends and challenges. Cadernos de Saude Publica, vol. 24, no. 12, pp. 2941-2947. http://dx.doi.org/10.1590/S0102311X2008001200024. PMid:19082286.

MARCELINO, A.P., SOUZA FILHO, J.A., BASTOS, C.V., RIBEIRO, S.R., MEDEIROS, F., REIS, I.A., LIMA, A., BARBOSA, J.R., PAZ, G.F. and GONTIJO, C., 2020. Comparative PCR-based diagnosis for the detection of Leishmania infantum in naturally infected dogs. Acta Tropica, vol. 207, pp. 105495. http://dx.doi.org/10.1016/j. actatropica.2020.105495. PMid:32305295.

MARCONDES, C.B., BITTENCOURT, I.A., STOCO, P.H., EGER, I., GRISARD, E.C. and STEINDEL, M., 2009. First report of natural infection of Nyssomyia neivai (Pinto, 1926) (Diptera: Psychodidae, Phlebotominae) by Leishmania braziliensis in Brazil. Transactions of the Royal Society of Tropical Medicine and Hygiene, vol. 103, no. 11, pp. 1093-1097. http://dx.doi. org/10.1016/j.trstmh.2008.12.006. PMid:19178921.

MARZOCHI, M.C.A., MARZOCHI, K.B.F., FAGUNDES, A. and CONCEIÇÃO-SILVA, F., 2014. A questão do controle das leishmanioses no Brasil. In: F. CONCEIÇÃO-SILVA and C. R. ALVES, eds. Leishmanioses do continente americano. Rio de Janeiro: Editora FIOCRUZ, pp. 431-464.

MAZIERO, N., THOMAZ-SOCCOL, V., STEINDEL, M., LINK,J.S., ROSSINI, D., ALBAN, S.M. and NASCIMENTO, A.J., 2014. Rural-urban focus of canine visceral leishmaniosis in the far western region of Santa Catarina State, Brazil. Veterinary Parasitology, vol. 205, no. 1-2, pp. 92-95. http://dx.doi.org/10.1016/j.vetpar.2014.06.005. PMid:25023635.

MORAES, M.H., GUARNERI, A.A., GIRARDI, F.P., RODRIGUES, J.B., EGER, I., TYLER, K.M., STEINDEL, M. and GRISARD, E.C., 2008. Different serological cross-reactivity of Trypanosoma rangeli forms in Trypanosoma cruzi-infected patients sera. Parasites E Vectors, vol. 1, no. 1, pp.20.http://dx.doi.org/10.1186/1756-3305-1-20. PMid:18611261.

MOYA, S.L., GIULIANI, M.G., MANTECA ACOSTA, M., SALOMÓN, O.D. and LIOTTA, D.J., 2015. First description of Migonemyia migonei (França) and Nyssomyia whitmani (Antunes \& Coutinho) (Psychodidae: Phlebotominae) natural infected by Leishmania infantum in Argentina. Acta Tropica, vol. 152, pp. 181-184. http:// dx.doi.org/10.1016/j.actatropica.2015.09.015. PMid:26409011.

ORLANDIN, E., D'AGOSTINI, F.M., PITALUGA, A.N., MARCONDES, C.B. and WAGNER, G., 2019. Notes on the Sand fly fauna (Diptera: Psychodidae: Phlebotominae) in municipalities along the Peixe River, Midwest of Santa Catarina, Brazil. Biota Amazônia, vol. 9, no. 3, pp. 67-69. http://dx.doi.org/10.18561/2179-5746/biotaamazonia.v9n3p67-69.

PASQUALI, A.K.S., BAGGIO, R.A., BOEGER, W.A., GONZALEZ-BRITEZ, N., GUEDES, D.C., CHAVES, E.C. and THOMAZ-SOCCOL, V., 2019. Dispersion of Leishmania (Leishmania) infantum in centralsouthern Brazil: evidence from an integrative approach. PLoS Neglected Tropical Diseases, vol. 13, no. 8, pp. e0007639. http:// dx.doi.org/10.1371/journal.pntd.0007639. PMid:31465422. 
PINA-TRENCH, F.., RITT, A.G., GEWEHR, T.A., SOUZA LEANDRO, A., CHIYO, L., RITTGEWEHR, M., RIPOLI, M., BISETTO, A., POZZOLO, E.M. and THOMAZ-SOCCOL, V., 2016. First report of autochthonous Visceral Leishmaniosis in humans in Foz do Iguaçu, Paraná State, Southern Brazil. Annals of Clinical Cytology and Pathology, vol. 2, no. 6, pp. 1041.

ROCHA, M.A.N., MATOS-ROCHA, T.J., RIBEIRO, C.M.B. and ABREU, S.R.O., 2018. Epidemiological aspects of human and canine visceral leishmaniasis in State of Alagoas, Northeast, Brazil. Brazilian Journal of Biology= Revista Brasileira de Biologia, vol. 78, no. 4, pp. 609-614 . http://dx.doi.org/10.1590/1519-6984.166622. PMid:29412243.

SALOMON, O.D., SINAGRA, A., NEVOT, M.C., BARBERIAN, G., PAULIN, P., ESTEVEZ, J.O., RIARTE, A. and ESTEVEZ, J., 2008. First visceral leishmaniasis focus in Argentina. Memórias do Instituto Oswaldo Cruz, vol. 103, no. 1, pp. 109-111. http://dx.doi.org/10.1590/S007402762008000100018 . PMid:18368242.

SAMBROOK, J. and RUSSEL, D.W., 2001. Molecular cloning. USA: Cold Spring Harbor Laboratory Press.

SILVEIRA, A.P.S., VIEIRA, V.B.D., BATALINI, L.S., CARMO, S.B., FRIOZI, E., ARRUDA, E.J., LIMA JUNIOR, M.S.C. and NEITZKE-ABREU, H.C., 2018. PCR sensitivity of peripheral blood of dogs co-infected with Leishmania spp. and Ehrlichia spp. in endemic area of Brazil. Revista da Sociedade Brasileira de Medicina Tropical, vol. 51, no. 6, pp. 843-847. http://dx.doi.org/10.1590/0037-8682-0040-2018. PMid:30517541.
STEINDEL, M., MENIN, A., EVANGELISTA, T., STOCO, P.H., MARLOW, M.A., FLEITH, R.C., PILATI, C. and GRISARD, E.C., 2013. Outbreak of autochthonous canine visceral leishmaniasis in Santa Catarina, Brazil. Pesquisa Veterinária Brasileira, vol. 33, no. 4, pp. 490-496. http://dx.doi.org/10.1590/S0100$736 X 2013000400013$.

SZARGIKI, R., CASTRO, E.A., LUZ, E., KOWALTHUK, W., MACHADO, A.M. and THOMAZ SOCCOL, V., 2009. Comparison of serological and parasitological methods for cutaneous leishmaniasis diagnosis in the state of Parana, Brazil. The Brazilian Journal of Infectious Diseases, vol. 13, no. 1, pp. 4752. http://dx.doi.org/10.1590/S1413-86702009000100011. PMid:19578630.

TORRES-GUERRERO, E., QUINTANILLA-CEDILLO, M.R., RUIZESMENJAUD, J. and ARENAS, R., 2017. Leishmaniasis: a review. F1000 Research, vol. 6, pp. 750. http://dx.doi.org/10.12688/ f1000research.11120.1. PMid:28649370.

WORLD HEALTH ORGANIZATION - WHO, 2017 [viewed 20 March 2020]. Leishmaniasis [online]. Informe Epidemiológico das Américas, no. 5. Available from: http://iris.paho.org/xmlui/ bitstream/handle/123456789/34113/informe_leishmanioses_5_ por.pdf? sequence $=1$ \&isAllowed $=\mathrm{y}$ 